\title{
EKSTRAKSI ASAM SITRAT DAN ASAM OKSALAT : PENGARUH TRIOCTYLAMINE SEBAGAI EXTRACTING POWER DALAM BERBAGAI SOLVEN CAMPURAN TERHADAP KOEFISIEN DISTRIBUSI
}

\author{
Mega Kasmiyatun ${ }^{1 *}$ dan Bakti Jos ${ }^{2)}$ \\ ${ }^{1)}$ Program Studi Teknik Kimia Fakultas Teknik Universitas 17 Agustus 1945 (UNTAG) Semarang \\ Jl. Pawiyatan Luhur Bendan Dhuwur Semarang 50233, Telp. (024)8441772 \\ ${ }^{*}$ Penulis korespondensi: megapramudono@yahoo.com \\ ${ }^{2)}$ Jurusan Teknik Kimia Fakultas Teknik UNDIP Semarang \\ Jl. Prof. Soedarto, SH, Tembalang, Semarang 50239, Telp.(024)7460058
}

\begin{abstract}
Generally, liquid waste of citric acid industry containing a highly citric acid, oxalic acid, due to precipitation process of calcium citrate less completely. Liquid-liquid extraction process is this one alternative that used to recover citric acid and oxalic acid, either in the product separation process from the fermentor or the treatment of its liquid waste. In order to understand, that the extraction process can be applied both technically and economically, it needs a more study the extraction parameters. The investigation has carried out about study of the extraction of citric acid and oxalic acid used trioctyl-amine as extracting power on various mix solvent and its ratio, related to the distribution coefficient. Extraction used a separating funnel that it was shaked with using an automatic shaker, which adjusted on specific velocity during 2.5 hours. The rafinate and extract were separated by separating funnel, then they were analyzed both concentration of citric acid and oxalic acid using a high performance liquid chromatography (HPLC). The results of the research show that the mixed solvent (consist of 15\% trioctyl amine, 70\% dodecane, and 15\% hexanol), for the extraction of citric acid produce both the highest distribution coefficient and percentage of separation were 1.15 and $74.22 \%$, respectively; and this were achieved for the ratio between the solvent and diluent of 2.5:1. For the extraction of oxalic acid similar result were obtained, and the value were 3.78 and $88.31 \%$, respectively, for the ratio between solvent and diluent of 2:1.
\end{abstract}

Keywords: citric acid, dodecane, distribution coefficient, extraction, hexanol, oxalic acid, trioctyl amine

\begin{abstract}
Abstrak
Limbah cair pabrik asam sitrat pada umumnya mengandung asam sitrat, asam oksalat, cukup tinggi akibat proses pengendapan calsium sitrat yang kurang sempurna. Proses ekstraksi cair-cair adalah salah satu alternatif yang dapat digunakan untuk pengambilan kembali asam sitrat dan asam oksalat, baik pada proses pemisahan produk yang keluar dari fermentor maupun pada proses pengolahan limbah cairnya. Untuk mengetahui apakah proses ekstraksi dapat diterapkan secara teknis, maka perlu dilakukan pengkajian lebih mendalam parameter-parameter ekstraksi. Pada penelitian ini telah dilakukan pengkajian tentang ekstraksi asam sitrat dan asam oksalat dengan menggunakan trioctylamine sebagai extracting power pada bermacam solven campuran dan pada berbagai perbandingan, hubungannya dengan koefisien distribusinya. Ekstraksi pada berbagai kondisi rancangan percobaan dilakukan pada corong pemisah, yang penggojokannya dilakukan dengan bantuan automatic shaker yang di set pada kecepatan tertentu selama 2,5 jam. Rafinat dan ekstrak dipisahkan selanjutnya dianalisis kadar asam sitrat maupun asam oksalat dengan menggunakan HPLC. Hasil penelitian menunjukkan bahwa solven campuran (yang terdiri dari 15\% trioctylamine, $70 \%$ dodecane dan 15\% hexanol) menghasilkan koefisien distribusi dan persentase pemisahan solute berturut-turut untuk asam sitrat 1,15 dan 74,22\% pada perbandingan solven dan diluen 2,5:1; sedang untuk ekstraksi asam oksalat sebesar 3,78 dan 88,31\% pada perbandingan solven dan diluen 2:1.
\end{abstract}

Kata kunci: asam sitrat, dodecane, koefisien distribusi, ekstraksi, hexanol, asam oksalat, trioctylamine 


\section{PENDAHULUAN}

Perkembangan agroindustri di Indonesia maupun negara-negara dikawasan Asia berlangsung cukup pesat, karena kawasan ini merupakan negara agraris yang kaya dengan aneka ragam tumbuhan hayati sebagai sumber bahan bakunya. Hampir semua agroindustri menghasilkan limbah cukup besar yang mengandung berbagai senyawa, dimana limbahnya seringkali dibuang langsung ke perairan sehingga mengakibatkan pencemaran.

Salah satu contoh industri agro adalah industri asam sitrat yang menggunakan bahan baku tapioka, dimana melalui proses fermentasi akan dihasilkan asam sitrat sebagai produk utama, dan asam oksalat sebagai produk ikutan akibat reaksi samping yang terjadi. Proses fermentasi menghasilkan produk keluar fermentor mengandung $14 \%$ asam sitrat, yang selanjutnya dipisahkan asam oksalatnya dengan cara diendapkan sebagai kalsium sitrat sebelum dikonversi kembali menjadi asam sitrat. Akibat proses pengendapan yang kurang sempurna maka akan dihasilkan limbah yang mengandung asam sitrat, asam oksalat, COD, dan BOD cukup tinggi, yang pengolahan limbahnya lazim menggunakan cara biologi.

Proses ekstraksi cair-cair adalah salah satu alternatif yang dapat digunakan untuk pengambilan kembali asam sitrat dan asam oksalat pada industri asam sitrat baik pada proses pemisahan produk yang keluar dari fermentor maupun pada proses pengolahan limbah cairnya. Untuk mengetahui apakah proses ekstraksi lebih layak dibanding proses yang sudah dipakai selama ini, maka diperlukan pengkajian yang lebih mendalam. Pengkajian tersebut meliputi pemilihan solven yang sesuai, studi parameterparameter ekstraksi yang berguna untuk perancangan peralatan ekstraksi maupun analisis ekonominya.

Parameter penting dalam ekstraksi cair-cair meliputi koefisien distribusi, selektivitas solven, dan perbandingan solven/umpan. Ekstraksi menggunakan solven konvensional seperti alkohol, eter, dan keton adalah tidak efisien apabila diterapkan pada larutan yang kadar asam karboksilatnya rendah (seperti asam sitrat dan oksalat) karena memberikan koefisien distribusi yang kecil (Jos, 2005). Di samping itu solven tersebut (terutama alkohol) mempunyai kelarutan yang cukup besar dalam air sehingga kurang cocok bila dipakai sebagai ekstraktan dalam pengolahan limbah cair. Senyawa amin terutama amin tersier lebih cocok dipakai sebagai extracting power untuk pengikat asamasam karboksilat karena dapat membentuk formasi asam-amin kompleks sehingga dapat meningkatkan harga koefisien distribusi. Kelemahan solven amin ini adalah tidak ekonomis apabila dipakai sebagai solven tunggal karena harganya sangat mahal dan mempunyai viskositas yang tinggi. Oleh karena itu perlu dikaji pemakaian solven campuran yang harganya jauh lebih murah namun tetap memberikan harga koefisien distribusi yang besar.
Beberapa penelitian tentang parameter ekstraksi dengan menggunakan solven amin dari jenis trioctylamine (TOA) telah banyak dilakukan. Marinova et al (2004) melakukan penelitian tentang pengambilan asam tartrat dari limbah industri anggur dengan menggunakan solven TOA, tributylphosphate (TBP) dan decanol, dodecane sebagai solven campuran pada berbagai perbandingan. Penelitian lain juga telah dilakukan seperti penentuan koefisien partisi dari ekstraksi asam sitrat, asam asetat, dan asam oksalat dengan menggunakan extracting power TOA dan berbagai solven yaitu toluene, methylisobutylketone, dan chloroform (Kirsch et al, 1997; Kirsch and Maurer, 1997; 1998a; 1998b; Schunk et al, 2004); pemungutan kembali (recovery) asam tartrat dengan TOA dalam diluen biner (Yankov et al, 1999); kajian pengaruh asam-asam anorganik dan garam-garam natrium (Ingale and Mahajani, 1996); kajian pH (Tomovska et al, 1999; Choudhury et al, 1998; Hong, 2005). Pengaruh solven TOA, di(2ethylhexyl) phosphoric acid dan xylene pada ekstraksi asam laktat serta pengaruh komposisi fase organik dan temperatur telah diteliti oleh Juang and Huang (1997) sedangkan campuran ekstraktan TOA, Aliquat 336 dan 1-decanol dikaji oleh Kyuchoukov et al (2001). Qin et al (2001) melaporkan hasil penelitiannya tentang ekstraksi asam oksalat dengan menggunakan solven TOA dan mengusulkan bentuk mekanismenya.

Dari berbagai penelitian yang telah disebutkan terdahulu menunjukkan bahwa ektraksi asam sitrat dan oksalat dengan menggunakan amin sebagai extracting power yang dilarutkan pada berbagai solven belum banyak dikaji terutama pengaruh konsentrasi solute dalam diluen, dan perbandingan antara solven dan diluen terhadap koefisien distribusi.

Makalah ini akan membahas tentang studi parameter ekstraksi yaitu koefisien distribusi pada ekstraksi asam sitrat dan asam oksalat dengan menggunakan extracting power trioctylamine (TOA) dan solven campuran dari berbagai kemungkinan senyawa alkohol atau senyawa aliphatik, baik rantai menengah maupun rantai panjang (hexanol, octanol, dan dodecane)

\section{Koefisien Distribusi}

Koefisien distribusi atau koefisien partisi (partition coefficient), $\mathrm{K}$ didefinisikan sebagai perbandingan antara fraksi berat solute dalam fase ekstrak, $\left(\mathrm{x}_{\mathrm{C}}\right)_{\mathrm{E}}$ dibagi dengan fraksi berat solute dalam fase rafinat, $\left(\mathrm{x}_{\mathrm{C}}\right)_{\mathrm{R}}$ pada keadaan kesetimbangan.

$$
K=\frac{\left(x_{C}\right)_{E}}{\left(x_{C}\right)_{R}}
$$

Koefisien distribusi dapat juga dinyatakan dalam fraksi mol

$$
\mathrm{K}^{\mathrm{o}}=\frac{\mathrm{y}^{\mathrm{o}}}{\mathrm{x}^{\mathrm{o}}}
$$


dimana $\mathrm{x}^{\mathrm{o}}, \mathrm{y}^{\mathrm{o}}$ masing-masing adalah fraksi mol solut dalam fase rafinat dan fase ekstrak.

\section{Aspek Thermodinamika dan Kinetika}

Dalam sistem cairan-cairan terner semua komponen (komponen A, B, dan C) terdapat pada kedua fase cairan, baik fase ekstrak maupun fase rafinat. Pada kondisi kesetimbangan, aktifitas $\mathrm{A}^{*}$ dari setiap komponen adalah sama pada kedua fase, yang didefinisikan sebagai berikut :

$$
A_{r}^{o}=\gamma_{r} x^{o}=A_{e}^{o}=\gamma_{e} y^{o}
$$

dimana $\mathrm{A}^{\mathrm{o}}$ adalah aktifitas solut; $\gamma$ adalah koefisien aktifitas solut; $r$ dan e menunjukkan fase rafinat dan fase ekstrak.

Dari persamaan (2) dan (3) didapat koefisien distribusi dalam term koefisien aktifitas sebagai berikut :

$$
\mathrm{K}^{\mathrm{o}}=\frac{\mathrm{y}^{\mathrm{o}}}{\mathrm{x}^{\mathrm{o}}}=\frac{\gamma_{\mathrm{r}}}{\gamma_{\mathrm{e}}}
$$

Koefisien aktifitas $\gamma$ didefinisikan sebagai kecenderungan suatu komponen untuk menyimpang dari keadaan idealnya yang ditunjukkan oleh penyimpangan relatif terhadap hukum Raoult dalam kesetimbangan uap-cair. Hukum Raoult yang dimodifikasi ditunjukkan oleh persamaan berikut :

$$
\mathrm{y}_{\mathrm{i}} \mathrm{P}=\mathrm{x}_{\mathrm{i}} \gamma_{\mathrm{i}} \mathrm{P}_{\mathrm{i}}
$$

Dimana $\mathrm{y}_{\mathrm{i}}$ dan $\mathrm{x}_{\mathrm{i}}$ berturut-turut adalah fraksi komponen volatil dalam fase uap dan cairan; $\gamma_{i}$ adalah koefisien aktifitas; $\mathrm{P}_{\mathrm{i}}$ dan $\mathrm{P}$ masing-masing adalah tekanan uap komponen volatil dan tekanan total sistem. Apabila harga $\gamma=1$, disebut larutan ideal, artinya tidak ada penyimpangan terhadap hukum Raoult, atau penyimpangannya sama dengan nol. Sebaliknya apabila $\gamma>1$ disebut penyimpangannya positif, sedangkan apabila $\gamma<1$ menunjukkan penyimpangannya negatif.

Dalam ekstraksi dikehendaki bahwa interaksi solut dan solven dalam fase ekstrak menunjukkan penyimpangan negatif terhadap hukum Raoult. Atau dengan kata lain harga koefisien aktifitasnya $\left(\gamma_{\mathrm{e}}\right)$ lebih kecil dari satu. Sebaliknya dalam fase rafinat, diinginkan interaksinya menunjukkan penyimpangan positif, atau harga $\gamma_{\mathrm{r}}$ lebih besar dari satu. Akibatnya apabila harga-harga koefisien aktifitas tersebut dimasukkan ke dalam persamaan (5), maka akan menghasilkan koefisien distribusi yang besar. Penyimpangan negatif dari hukum Raoult akan meningkatkan koefisien distribusi, namun juga menyebabkan terbentuknya azeotrop dengan maximum boiling point. Konsep ini dapat digunakan untuk metode penjaringan solven-solven yang cocok untuk suatu operasi ekstraksi tertentu.

\section{Kesetimbangan Ekstraksi}

Model kesetimbangan pada ekstraksi larutan asam dikarboksilat dalam air dengan menggunakan solven TOA adalah dengan menganggap bahwa ada dua macam reaksi yang terjadi, yaitu (1) disosiasi asam dalam larutan encer dan (2) pembentukan produk reaksi 'acid-solvent'. Dalam menerangkan model kesetimbangan ini diambil asumsi bahwa kelarutan TOA dalam aqueous phase (rafinat) diabaikan dan TOA hanya bereaksi dengan asam karboksilat yang tidak terdisosiasi (Marinova et al, 2004; Hong and Hong, 2005; Poposka et al, 1998).

Reaksi disosiasi berlangsung 2 tahap

Tahap I : $\mathrm{H}_{2} \mathrm{~A} \leftrightarrow \mathrm{HA}^{-}+\mathrm{H}^{+}$

$$
\mathrm{K}_{\mathrm{a} 2,1}=\frac{\left[\mathrm{HA}^{-}\right]\left[\mathrm{H}^{+}\right]}{\left[\mathrm{H}_{2} \mathrm{~A}\right]}
$$

Tahap II : $\mathrm{HA}^{-} \leftrightarrow \mathrm{H}^{+}+\mathrm{A}^{2-}$

$$
\mathrm{K}_{\mathrm{a} 2,2}=\frac{\left[\mathrm{H}^{+}\right]\left[\mathrm{A}^{2-}\right]}{\left[\mathrm{HA}^{-}\right]}
$$

dimana: $\mathrm{K}_{\mathrm{a} 2,1}$ dan $\mathrm{K}_{\mathrm{a} 2,2}$ adalah konstanta disosiasi tahap I dan tahap II dari asam dikarboksilat.

Reaksi pembentukan acid-solvent:

$$
\mathrm{H}_{2} \mathrm{~A}+\mathrm{n}_{2} \overline{\text { Solv. }} \leftrightarrow \overline{\mathrm{H}_{2} \text { A.Solv. }_{\text {.n2 }}}
$$

dimana $n_{2}$ adalah jumlah molekul solven yang berasosiasi dengan satu molekul asam; Solv. adalah solven (TOA) atau ekstraktan; dan $\overline{\mathrm{H}_{2} \mathrm{~A}_{\text {Solv }} \mathrm{S} 1}$ adalah produk (dicarboxylic) acid-solvent (berada dalam fase ekstrak), dengan konstanta ekstraksi :

$$
\mathrm{K}_{\mathrm{E} 2}=\frac{\left[\overline{\mathrm{H}_{2} \mathrm{~A} \cdot \text { Solv }_{\mathrm{n} 2}}\right.}{\left[\mathrm{H}_{2} \mathrm{~A}\right]\left[\overline{\text { Solv. }}^{\mathrm{n} 2}\right.}
$$

Koefisien distribusi dikarboksilat dinyatakan oleh persamaan:

$$
\mathrm{K}_{2}=\frac{\overline{\mathrm{C}_{\mathrm{H}_{2} \mathrm{~A}}}}{\mathrm{C}_{\mathrm{H}_{2} \mathrm{~A}}}=\frac{\left[\overline{\mathrm{H}_{2} \mathrm{~A} \cdot \text { Solv }_{{ } 2}}\right]}{\left[\mathrm{H}_{2} \mathrm{~A}\right]+\left[\mathrm{HA}^{-}\right]+\left[\mathrm{A}^{2^{-}}\right]}
$$

dimana $\mathrm{K}_{2}$ adalah koefisien distribusi asam dikarboksilat; $\overline{\mathrm{C}}_{\mathrm{H}_{2} \mathrm{~A}}$ dan $\mathrm{C}_{\mathrm{H}_{2} \mathrm{~A}}$ masing-masing adalah total konsentrasi asam dalam bentuk apapun dalam fase ekstrak dan fase rafinat.

Dalam hal asam trikarboksilat, reaksi disosiasi berlangsung 3 tahap

$$
\begin{array}{ll}
\text { Tahap I : } & \mathrm{H}_{3} \mathrm{~A} \leftrightarrow \mathrm{H}_{2} \mathrm{~A}^{-}+\mathrm{H}^{+} \\
\mathrm{K}_{\mathrm{a} 3,1}=\frac{\left[\mathrm{H}_{2} \mathrm{~A}^{-}\right]\left[\mathrm{H}^{+}\right]}{\left[\mathrm{H}_{3} \mathrm{~A}\right]} \\
\text { Tahap II : } \mathrm{H}_{2} \mathrm{~A}^{-} \leftrightarrow \mathrm{HA}^{2-}+\mathrm{H}^{+} \\
\mathrm{K}_{\mathrm{a} 3,2}=\frac{\left[\mathrm{HA}^{2-}\right]\left[\mathrm{H}^{+}\right]}{\left[\mathrm{H}_{2} \mathrm{~A}^{-}\right]}
\end{array}
$$

Tahap III : $\mathrm{HA}^{-2} \leftrightarrow \mathrm{A}^{3-}+\mathrm{H}^{+}$ 


$$
\mathrm{K}_{\mathrm{a} 3,2}=\frac{\left[\mathrm{A}^{3-}\right]\left[\mathrm{H}^{+}\right]}{\left[\mathrm{HA}^{2-}\right]}
$$

dimana $\mathrm{K}_{\mathrm{a} 3,1}, \mathrm{~K}_{\mathrm{a} 3,2}$ dan $\mathrm{K}_{\mathrm{a} 3,3}$ adalah konstanta disosiasi tahap I, tahap II dan tahap III dari asam trikarboksilat.

Reaksi pembentukan acid-solvent:

$$
\mathrm{H}_{3} \mathrm{~A}+\mathrm{n}_{2} \overline{\text { Solv. }} \leftrightarrow \overline{\mathrm{H}_{3} \mathrm{~A} . \text { Solv }_{\text {.n } 3}}
$$

dimana $n_{3}$ adalah jumlah molekul solven yang berasosiasi dengan satu molekul asam; Solv. adalah solven (TOA) atau ekstraktan; dan $\overline{\mathrm{H}_{3} \mathrm{~A} . \mathrm{Solv}_{2} \mathrm{n}_{3}}$. adalah produk (tricarboxylic) acid-solvent (berada dalam fase ekstrak), dengan konstanta ekstraksi :

$$
\mathrm{K}_{\mathrm{E} 3}=\frac{\left[\overline{\mathrm{H}}_{3} \mathrm{~A} \cdot \text { Solv }_{\mathrm{n} 3}\right.}{\left[\mathrm{H}_{3} \mathrm{~A}\right]\left[\overline{\text { Solv. }}_{\mathrm{n}}\right]^{\mathrm{n3}}}
$$

Koefisien distribusi trikarboksilat dinyatakan oleh persamaan:

$$
\mathrm{K}_{3}=\frac{\overline{\mathrm{C}_{\mathrm{H}_{3} \mathrm{~A}}}}{\mathrm{C}_{\mathrm{H}_{3} \mathrm{~A}}}=\frac{\left[{\overline{\mathrm{H}_{3} \mathrm{~A} \cdot \text { Solv }_{\mathrm{n}_{3}}}}^{2-}\right]}{\left[\mathrm{H}_{3} \mathrm{~A}\right]+\left[\mathrm{H}_{2} \mathrm{~A}\right]+\left[\mathrm{HA}^{2-}\right]+\left[\mathrm{A}^{3^{-}}\right]}
$$

dimana $\mathrm{K}_{3}$ adalah koefisien distribusi asam trikarboksilat; $\overline{\mathrm{C}}_{\mathrm{H}_{3} \mathrm{~A}}$ dan $\mathrm{C}_{\mathrm{H}_{3} \mathrm{~A}}$ masing-masing adalah total konsentrasi asam dalam bentuk apapun dalam fase ekstrak dan fase rafinat.

Zat cair dan zat padat berbeda dengan gas, dimana perbedaannya adalah, pada molekul-molekul zat cair atau zat padat terjadi ikatan yang sangat kuat antar molekulnya. Untuk memperoleh larutan, suatu solven harus mengalahkan ikatan yang kuat pada solut sehingga molekul-molekul solven mendapatkan tempat. Sebaliknya pada saat yang bersamaan molekul-molekul solven itu sendiri harus dapat dipisahkan satu dengan lainnya oleh molekul-molekul solut. Fenomena ini terjadi kalau gaya tarik menarik antara molekul kedua komponen tersebut adalah sama. Jika gaya tarik menarik cukup berbeda, maka molekulmolekul yang gaya tarik menariknya lebih kuat akan terikat bersama dan memisahkan diri dari molekulmolekul yang gaya tarik menariknya lebih lemah, di mana hasilnya adalah cairan yang tidak dapat tercampur homogen (immiscible liquids). Minyak dan air tidak dapat bercampur sebab gaya tarik menarik antar molekul-molekul air lebih kuat dibanding gaya tarik menarik molekul-molekul minyak sendiri, sehingga tidak ada kesempatan bagi molekul-molekul minyak berada diantara molekul-molekul air. Gayagaya ikat antar molekul-molekul tersebut disebut gaya van der Waals yang sesungguhnya disebabkan adanya interaksi elektromagnetik (interaksi polar) antar molekul yaitu gaya polar (polar forces), gaya dispersi (dispersion force) dan gaya ikatan hidrogen (hydrogen bonding forces).

\section{METODE PENELITIAN}

\section{Bahan-bahan Kimia}

Bahan-bahan kimia yang dipakai semuanya p.a. (pro analysis) dimana diperoleh dari supplier tanpa perlakuan lebih lanjut, meliputi asam sitrat (minimal $99 \%$, Merck) dan asam oksalat (99,5\%, Merck) sebagai solute; trioctylamine ( $93,0 \%$, Merck) sebagai extracting power; octanol (minimal 99,0\%, Merck), hexanol (minimal 98,0\%, Merck), dodecane (minimal $99,0 \%$, Merck) dan tributyl phosphate (minimal 99,0\%, Merck) sebagai solvent campuran.

\section{Penetapan Variabel}

Variabel yang berubah :

1. Perbandingan berat diluen/solven $=1: 1 ; 1: 1,5$; $1: 2 ; 1: 2,5 ; 1: 3 ; 1: 3,5 ;$ dan $1: 4$. Variabel tetap adalah temperatur $\left(30^{\circ} \mathrm{C}\right)$, tekanan $(1 \mathrm{~atm})$, perbandingan berat extracting power (TOA): solvent (dodecane) (15:85), konsentrasi solute (asam sitrat) dalam diluen (1400 ppm). Respons yang diamati adalah harga koefisien distribusi (K), persentase solute yang terpisah.

2. Perbandingan berat (TOA) extractant solvent: (dua macam) solvent $=15: 70: 15$. Variabel tetap adalah temperatur $\left(30^{\circ} \mathrm{C}\right)$, tekanan $(1 \mathrm{~atm})$, perbandingan berat diluen dan solvent $=$ perbandingan yang optimum (hasil dari 1) yang menghasilkan harga $\mathrm{K}$ terbesar, konsentrasi asam sitrat dalam diluent (1400 ppm). Respons yang diamati adalah harga koefisien distribusi $(\mathrm{K})$, persentase solute yang terpisah.

3. Mengulangi langkah 2) tetapi memakai solven tunggal yaitu TOA, dodecane.

4. Mengulangi langkah 1) dan 2), dengan konsentrasi asam oksalat dalam diluen $1600 \mathrm{ppm}$. Respons yang diamati adalah harga koefisien distribusi (K), persentase solute yang terpisah.

\section{Cara Percobaan}

Larutan asam sitrat (asam sitrat sebagai solute dan air sebagai diluen) ditambah solven (TOA + dodecane) dengan perbandingan berat yang bervariasi dalam sebuah corong pemisah sebagai alat pengontak (extractor). Perbandingan berat TOA dan dodecane adalah $15 \%: 85 \%$. Campuran diaduk dalam suatu alat penggoyang (electronic shaker) pada kondisi normal $\left(30^{\circ} \mathrm{C}, 1 \mathrm{~atm}\right)$ dengan kecepatan tertentu selama 2,5 jam. Waktu pengadukan ini sudah cukup untuk proses keseimbangan antar fase, sebab setelah 2 jam saja kadar asam di masing-masing fase sudah stabil atau tidak berubah lagi. Campuran kemudian didiamkan selama 1 jam untuk memberi kesempatan kedua fase ekstrak dan rafinat terpisah sempurna. Setelah kedua fase dipisahkan, selanjutnya masing masing fase dianalisis kadar solutenya (asam sitrat) dengan menggunakan HPLC (High Performance Liquid Chromatography), dimana hasilnya adalah konsentrasi asam sitrat pada fase ekstrak maupun pada fase rafinat, sehingga dapat dihitung koefisien distribusinya. HPLC terdiri dari Liquid 
Chromatograph LC 20 AT, UV-Vis detector SPD 20A, kolom tipe VP-ODS 250Lx4.6 ukuran $4.6 \mathrm{mm \Phi}$ x 250 $\mathrm{mm}$. Alat dioperasikan pada constant flow 0.8 $\mathrm{ml} /$ menit dan tekanan 78 psia; column oven dipertahankan pada suhu $30^{\circ} \mathrm{C}$; panjang gelombang UV-Vis detector $\lambda=210 \mathrm{~nm}$. Larutan eluen menggunakan $\mathrm{H}_{2} \mathrm{SO}_{4} 0.005 \mathrm{M}$ dan metanol p.a. dengan perbandingan 9:1. Percobaan diulangi dengan variasi yang lain sesuai dengan variabel-variabel yang ditetapkan dalam penelitian ini, dan selanjutnya dilakukan analisis diskriptif.

\section{HASIL DAN PEMBAHASAN}

\section{Pengaruh Perbandingan Solven/Diluen}

Pengaruh perbandingan solven dan diluen terhadap koefisien distribusi $(\mathrm{K})$ ekstraksi asam sitrat dengan menggunakan campuran solven (15\% TOA; $85 \%$ dodecane) ditunjukkan pada Gambar 1, sedangkan persentase asam sitrat yang dapat dipisahkan seperti terlihat pada Gambar 2.

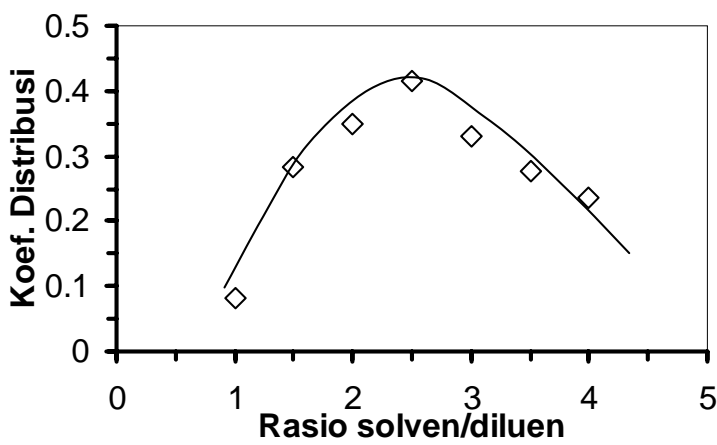

Gambar 1. Hubungan koefisien distribusi dengan rasio solven/diluen ekstraksi asam sitrat dengan solven campuran TOA (15\%)-dodecane (85\%).

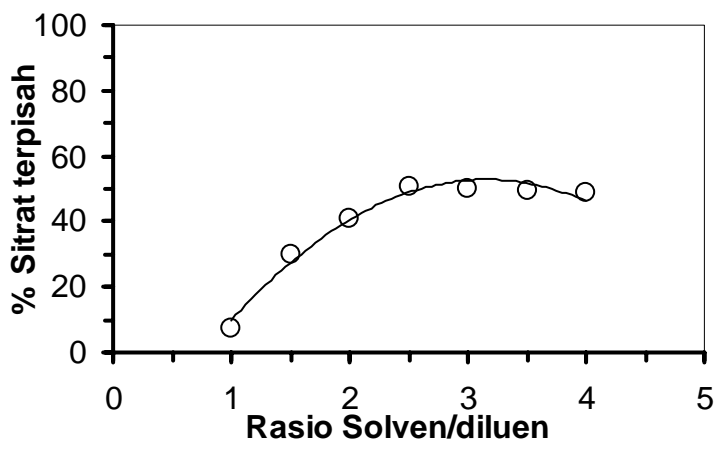

Gambar 2. Hubungan persentase asam sitrat yang terpisah dengan rasio solven/diluen ekstraksi asam sitrat dengan solven campuran TOA (15\%)-dodecane $(85 \%)$.

Harga $\mathrm{K}$ mengalami kenaikan seiring dengan kenaikan rasio solven dan diluen, sampai mencapai maksimum pada rasio 2,5:1; selanjutnya $\mathrm{K}$ mengalami penurunan apabila rasio dibesarkan (Gambar 1). Kecenderungan sama juga terjadi pada persentase asam sitrat yang terpisah di mana mengalami maksimum juga pada rasio 2,5:1 (Gambar 2). Harga maksimum koefisien distribusi dan persentase asam sitrat yang terpisah pada perbandingan solven dan diluen 2,5:1 sebesar masing-masing 0,41 dan 50,90\%.

Gambar 3 menunjukkan pengaruh perbandingan solven dan diluen terhadap koefisien distribusi (K) ekstraksi asam oksalat dengan menggunakan campuran solven (15\% TOA; 85\% dodecane), sedangkan persentase asam oksalat yang dapat dipisahkan pada kondisi ekstraksi ini seperti terlihat pada Gambar 4. Sebagaimana seperti pada ekstraksi asam sitrat, harga $\mathrm{K}$ asam oksalat juga mengalami kenaikan seiring dengan kenaikan rasio solven dan diluen, sampai mencapai maksimum pada rasio 2:1; selanjutnya $\mathrm{K}$ mengalami penurunan apabila rasio dibesarkan (Gambar 3).

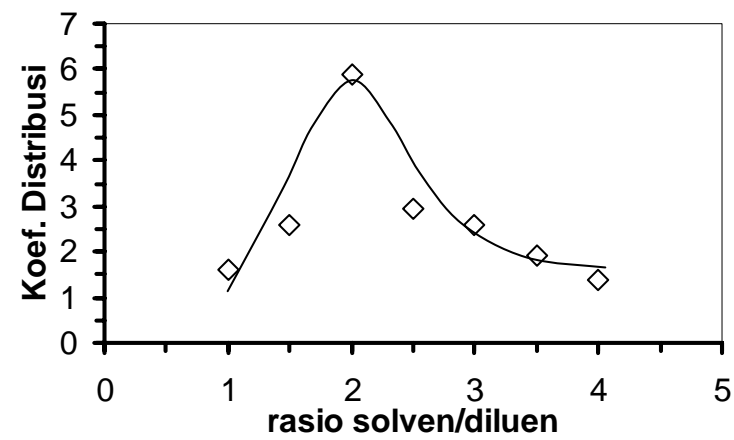

Gambar 3. Hubungan koefisien distribusi dengan rasio solven/diluen ekstraksi asam oksalat dengan solven campuran TOA (15\%)-dodecane (85\%).

Kecenderungan yang sama juga terjadi pada persentase asam oksalat yang terpisah yang juga mengalami harga maksimum pada rasio 2:1 (Gambar 4).

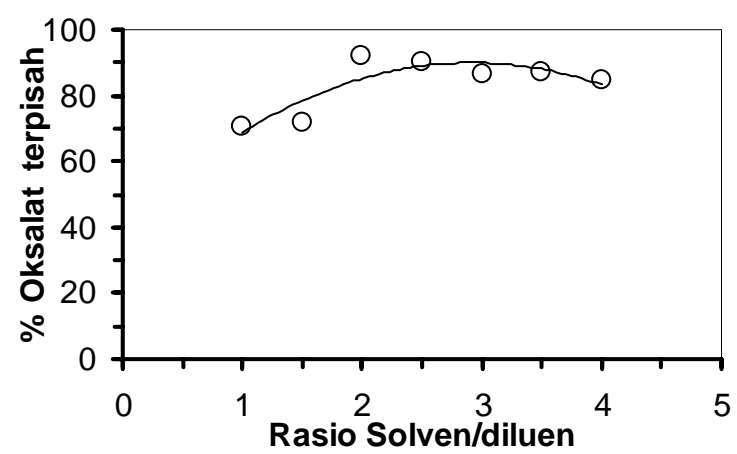

Gambar 4. Hubungan persentase asam oksalat yang terpisah dengan rasio solven/diluen ekstraksi asam oksalat dengan solven campuran TOA (15\%)dodecane $(85 \%)$.

Harga maksimum koefisien distribusi dan persentase asam oksalat yang terpisah pada perbandingan solven dan diluen 2:1 sebesar masingmasing 5.87 dan $92,15 \%$. 


\section{Kelarutan}

Larutnya asam sitrat atau asam oksalat (solute) dalam air (solven) pada hakekatnya adalah karena terpisahnya ikatan yang kuat antar molekul-molekul asam, dimana ruang-ruang tersebut selanjutnya digantikan oleh molekul-molekul solven yang dalam hal ini adalah air. Energi yang dibutuhkan untuk melepas ikatan antar partikel solute sesungguhnya didapat dari energi yang dihasilkan dari pembentukan ikatan antara partikel solute dan molekul solven. Ikatan yang terjadi pada molekul asam sitrat dan asam oksalat adalah ikatan ion yang mempunyai gaya tarik menarik elektrostatik yang cukup kuat. Hanya air atau solvensolven yang sangat polar mempunyai kemampuan untuk melarutkan solute yang mempunyai ikatan ion yang kuat tersebut. Air merupakan molekul polar dimana mempunyai kutub positif (pada atom $\mathrm{H}$ ) dan kutub negatif (pada atom $\mathrm{O}$ ), yang akibatnya terjadi tarik menarik elektrostatik antara ion (asam sitrat dan asam oksalat) yang bermuatan positif dengan kutub negatif dari air. Disamping itu terjadi ikatan tarik menarik antara kutub positif dari molekul air dengan ion negatif (atau kutub yang bermuatan negatif) dari molekul asam. Ikatan yang terakhir ini yang disebut ikatan hidrogen (hydrogen bond). Ikatan antara molekul solut (asam sitrat / asam oksalat) dan air lebih kuat dibanding dengan ikatan antar molekul air maupun ikatan antar molekul solute sendiri, sehingga terjadilah pelarutan solute di dalam solven air. Asam sitrat dengan rumus $\mathrm{C}(\mathrm{OH}) \mathrm{COOH}\left(\mathrm{CH}_{2} \mathrm{COOH}\right)_{2}$ mempunyai kutub bermuatan positif dan negatif lebih banyak dibanding asam oksalat yang mempunyai rumus $(\mathrm{COOH})_{2}$, sehingga dipastikan bahwa ikatan hidrogen antara asam sitrat dan air akan lebih besar dibanding ikatan hidrogen antara asam oksalat dan air. Hal ini berakibat kelarutan asam sitrat lebih besar daripada kelarutan asam oksalat dalam air. Dari data menunjukkan bahwa pada temperatur $20^{\circ} \mathrm{C}$ kelarutan asam sitrat adalah $133 \mathrm{~g} / 100 \mathrm{ml} \mathrm{H}_{2} \mathrm{O}$, sedang asam oksalat adalah $12 \mathrm{~g} / 100 \mathrm{ml} \mathrm{H} \mathrm{H}_{2} \mathrm{O}$.

\section{Solven}

TOA adalah senyawa amine tersier dengan tiga rantai alkyl panjang $\left(3 \mathrm{C}_{8} \mathrm{H}_{17}\right)$ yang bersifat hidrophobik, sehingga kelarutannya dalam aqueous phase (fase air) sangat kecil. Demikian pula dodecane adalah senyawa alkane rantai lurus yang mempunyai panjang rantai alkyl $12\left(\mathrm{C}_{12} \mathrm{H}_{25}\right)$ juga bersifat hydrophobic. Campuran keduanya akan menambah sifat hydrophobic solven terhadap diluen. Pada senyawa TOA ada 2 jenis interaksi polar yang berperan, yaitu gaya-gaya polar (polar forces) dan gaya ikatan hidrogen (hydrogen bonding force), sedangkan pada senyawa dodecane hanya berlaku gaya dispersi (dispersion force) meskipun tidak begitu kuat. Ditinjau dari sifat kelarutannya TOA yang merupakan amine tertier mempunyai kelarutan dalam air sangat kecil dan yang paling rendah dibanding dengan senyawa-senyawa amin primer maupun amin sekunder (Morrison and Boyd, 1992; Wade, 1999). Demikian pula dodecane yang bersifat hidrophobik sangat tidak larut dalam air. Meskipun demikian kedua solven ini mempunyai kekuatan ikatan dengan asam sitrat maupun dengan asam oksalat yang jauh lebih besar dibanding dengan ikatan asam-asam tersebut dengan air, sehingga dapat menggantikan ikatan yang sudah terbentuk antara asam dan air. Ikatan hidrogen antar senyawa amin, asam maupun antara amin dan asam tergolong ikatan hidrogen yang kuat (Burrel, 1955). Hal ini juga ditunjukkan terbentuknya ikatan baru yang lebih kuat yang berupa ikatan hidrogen maupun ikatan ion antara asam dan solven (acid-solvent) yang ditandai dengan melarutnya solute (asam-asam) ke dalam solven (Hong and Hong, 2005).

\section{Perbandingan Solven dan Diluen}

Interaksi antara asam sitrat maupun asam oksalat dengan TOA membentuk suatu senyawa kompleks asam sitrat-TOA maupun asam oksalatTOA seperti yang ditunjukkan pada Gambar 5. Gambar 5a dan 5b menunjukkan masing-masing senyawa komplek model pertama dari asam oksalatTOA, dan asam sitrat-TOA. Kedua model senyawa komplek tersebut sesungguhnya terbentuk karena adanya ikatan hidrogen.

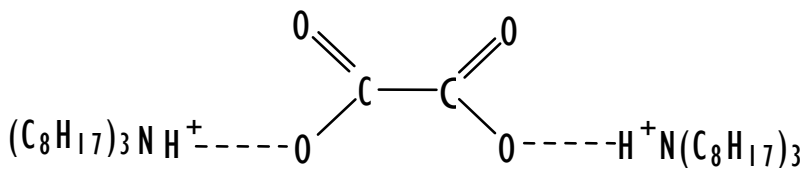

[a]

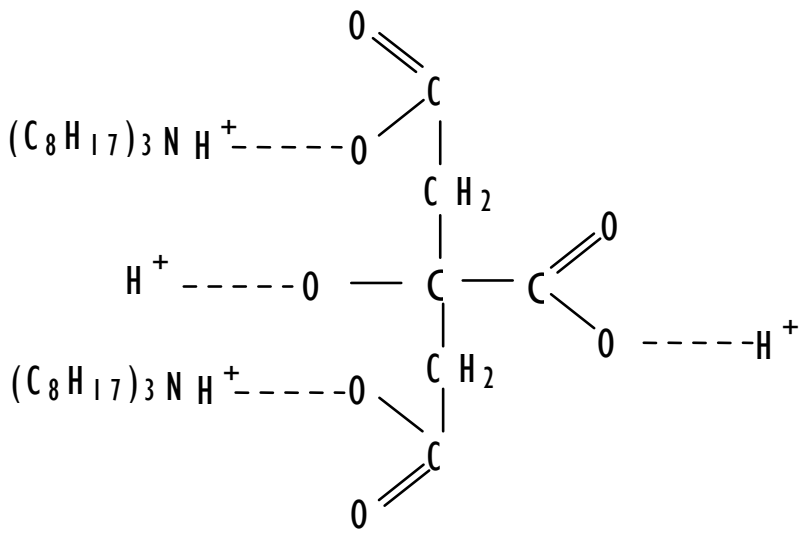

[b]

Gambar 5. Senyawa kompleks acid-solvent (a) asam oksalat-TOA; (b) asam sitrat-TOA

Kutub-kutub positif $\left[\mathrm{H}^{+}\right]$dari gugus-gugus $\mathrm{OH}$ dan $\mathrm{COOH}$ dari masing-masing asam tersebut membentuk ikatan hidrogen dengan kutub negatif $\left[\mathrm{N}^{-}\right]$ dari trioctyl amine (TOA). Disamping itu bisa saja terjadi senyawa komplek model kedua, di mana terjadi ikatan hidrogen lebih lanjut dari senyawa komplek model pertama, yang terbentuk antar sesama asam 
oksalat yaitu antara kutub negatif $\mathrm{O}$ yang bermuatan negatif berikatan dengan hidrogen dari asam oksalat yang bermuatan positif. Senyawa komplek model kedua juga bisa terjadi pada senyawa komplek asam sitrat-TOA, di mana kutub negatif $O$ dari asam sitrat yang bermuatan negatif berikatan dengan hidrogen dari sesama asam sitrat yang bermuatan positif. Apabila konsentrasi TOA dalam sistem bertambah maka pembentukan senyawa komplek model kedua akan berkurang. Ikatan hidrogen lebih kuat dan lebih mudah terbentuk antara $\mathrm{H}$ dengan $\mathrm{N}$ (dari amin tertier) dibanding antara $\mathrm{H}$ dengan $\mathrm{O}$ (dari gugus hidroksi atau karboksilat), karena gugus amin tertier lebih polar dibanding dengan gugus hidroksi maupun karboksilat. Hal ini dilihat dari momen ikatan $\mathrm{C} \equiv \mathrm{N}$ adalah 3.5 Debey, sedang $\mathrm{C}=\mathrm{O}$ sebesar 2.3 Debey.

Sehubungan kaitannya dengan pengaruh perbandingan solven dan diluen, mengandung pengertian bahwa makin besar perbandingannya maka jumlah TOA makin bertambah. Artinya pembentukan senyawa komplek pertama (Gambar 5a dan 5b) lebih dominan, sedangkan pembentukan senyawa komplek kedua berkurang. Terbentuknya senyawa komplek model pertama akan berada pada fase ekstrak, sedang senyawa komplek model kedua lebih cenderung berada pada fase rafinat. Hal ini menunjukkan bahwa Koefisien Distribusi mengalami kenaikan apabila senyawa komplek model pertama yang terbentuk banyak, dan juga berlaku sebaliknya. Proses ini berjalan terus menerus, seiring dengan kenaikan perbandingan solven dan diluen, sampai semua gugus karboksilat dan hidroksida dijenuhi oleh ikatan $\mathrm{H}$ dengan amine (N). Pada keadaan ini jumlah asam sitrat atau asam oksalat yang terekstrak mencapai harga maksimum, dimana apabila perbandingan solven dan diluen diperbesar lagi maka justru asam yang terekstrak menjadi berkurang. Dengan perkataan lain koefisien distribusi menurun. Fenomena tersebut digunakan untuk menerangkan Gambar 1 sampai dengan Gambar 4.

Pada kondisi perbandingan solven dan diluen yang sama menunjukkan bahwa baik jumlah solut yang terekstrak maupun koefisien distribusi dari asam oksalat selalu lebih tinggi daripada asam sitrat. Hal ini dapat diterangkan sebagai berikut. Seperti telah dibahas terdahulu bahwa asam oksalat maupun asam sitrat yang terlarut dalam diluen air hasil dari ikatan hidrogen, namun ikatan hidrogen antara asam oksalat dan air jauh lebih lemah dibanding dengan ikatan hidrogen antara asam sitrat dan air. Oleh sebab itu, solven TOA lebih mudah melepas dan mengganti ikatan asam oksalat-air daripada ikatan asam sitrat-air. Hasil dari penggantian ini berupa ikatan hidrogen asam-TOA atau senyawa acid-solvent yang berada pada fase ekstrak.

Kondisi maksimum perbandingan solven dan diluen dicapai untuk asam sitrat dan asam oksalat masing-masing sebesar 2,5:1 dan 2:1. Kondisi maksimum perbandingan solven dan diluen untuk asam oksalat lebih kecil daripada asam sitrat, artinya pembentukan ikatan hidrogen asam oksalat-TOA mencapai keadaan jenuh lebih dulu dibanding asam sitrat. Hal ini dapat dipahami karena untuk mencapai ikatan hidrogen yang jenuh, 1 mol asam oksalat hanya memerlukan 2 mol TOA untuk berikatan dengan $\mathrm{H}$ pada gugus karboksilatnya, sedangkan $1 \mathrm{~mol}$ asam sitrat memerlukan sampai 4 mol TOA (3 mol berikatan dengan $\mathrm{H}$ pada gugus karboksilat dan $1 \mathrm{~mol}$ berikatan dengan $\mathrm{H}$ pada gugus hidroksil).

Asam sitrat yang terekstraksi maksimum yang bisa dicapai pada perbandingan solven dan diluen 2,5:1 adalah sebesar 50,90\% (Gambar 2), sedang asam oksalat yang dapat dipisahkan dapat mencapai 92,15\% pada perbandingan 2:1 (Gambar 4). Hasil ini selaras dengan penelitian ekstraksi asam-asam organik dengan menggunakan solven campuran TOA dan chloroform yang dilakukan oleh Kirsch dan Maurer (1998), di mana menyimpulkan bahwa asam yang lebih kuat lebih mudah diekstraksi oleh solven amin. Asam sitrat merupakan asam yang lebih lemah dibanding dengan asam oksalat, di mana diketahui dari konstanta disosiasi asam sitrat jauh lebih rendah dibanding asam oksalat. Asam sitrat dalam diluen mengalami disosiasi 3 tahap, sedangkan pada asam oksalat hanya terjadi 2 tahap disosiasi. Harga konstanta disosiasi asam sitrat sebesar $\mathrm{K}_{\text {as } 1}=7.1 \times 10^{-4}$ $; \mathrm{K}_{\mathrm{as} 2}=1.7 \times 10^{-5} ;$ dan $\mathrm{K}_{\mathrm{as} 3}=3.9 \times 10^{-7}$, sedangkan harga konstanta disosiasi asam oksalat sebesar $\mathrm{K}_{\mathrm{aol}}=$ $5.9 \times 10^{-2}$ dan $\mathrm{K}_{\mathrm{ao2} 2}=6.5 \times 10^{-5}$.

Konsekuensi dari hasil asam-asam yang terekstrak seperti yang telah disebutkan, pasti berhubungan dengan parameter ekstraksi yaitu salah satunya adalah koefisien distribusi $(\mathrm{K})$, di mana $\mathrm{K}$ asam oksalat lebih besar daripada $\mathrm{K}$ asam sitrat, pada segala perbandingan solven dan diluen (Gambar 1 dan 3). Berdasarkan persamaan (12) dan (21) menyebutkan bahwa koefisien distribusi adalah perbandingan konsentrasi asam (dalam bentuk apapun) di dalam fase ekstrak $\left(\overline{\mathrm{C}}_{\mathrm{A}}\right)$ dibagi konsentrasi asam (dalam bentuk apapun) di dalam fase rafinat $\left(\mathrm{C}_{\mathrm{A}}\right)$. Konsentrasi asam dalam fase ekstrak adalah konsentrasi senyawa komplek yang terbentuk yaitu acid-solvent, sedangkan konsentrasi asam dalam fase rafinat meliputi sisa asam yang tidak terekstrak dan asam-asam hasil disosiasi pada masing-masing tahap. Jadi $\mathrm{C}_{\mathrm{A}}$ tergantung pada jenis atau kekuatan asam yang mempengaruhi banyaknya tahap disosiasi. Pada umumnya makin lemah suatu asam, maka makin banyak tahap disosiasinya sehingga harga $\mathrm{C}_{\mathrm{A}}$ makin besar. Asam sitrat merupakan asam lemah, di mana mengalami 3 tahap disosiasi sehingga koefisien distribusinya mengikuti persamaan (21), sedang asam oksalat yang lebih kuat daripada asam sitrat hanya terjadi 2 tahap disosiasi, maka mengikuti persamaan (12). Akibatnya $\mathrm{C}_{\mathrm{A}}$ asam sitrat jauh lebih besar dibanding $\mathrm{C}_{\mathrm{A}}$ asam oksalat. Hal tersebut menyebabkan koefisien distribusi asam sitrat lebih kecil dibanding koefisien distribusi asam oksalat. 


\section{Pengaruh Solven Campuran}

Pengaruh pemakaian jenis solven campuran terhadap persentase solut yang terekstrak dan koefisien distribusi seperti disajikan pada Tabel 1. Telah dicoba apabila sistem TOA-dodecane ditambah dengan berbagai jenis solven sehingga menjadi solven campuran dengan perbandingan berat tertentu yaitu TOA-dodecane-hexanol; TOA-dodecane-octanol; TOA-dodecane-tributyl phosphate. Untuk mengetahui apakah solven campuran mempunyai pengaruh yang cukup berarti, maka dicoba pula kekuatan solven TOA maupun docecane secara individual.

Dari Tabel 1 terlihat bahwa secara umum pemakaian ketiga solven campuran meningkatkan performa baik banyaknya solut yang berhasil diekstrak maupun koefisien distribusinya, dibanding pemakaian individual solven (TOA, dodecane, TOA-dodecane), dengan kekecualian sistem TOA-dodecane masih lebih unggul untuk ekstraksi asam oksalat. Secara umum pula performa pemisahan (baik persentase solut yang terekstrak maupun koefisien distribusi) asam oksalat lebih baik dibanding dengan asam sitrat. Hal ini selaras dengan apa yang telah dibahas dimuka.

TOA fungsinya sebagai extracting power, namun apabila digunakan secara individual hanya dapat mengekstrak asam sitrat dan asam oksalat berturut-turut sebesar $23,93 \%$ dan $84,84 \%$ saja. Koefisien distribusinyapun kecil yaitu 0,126 untuk ekstraksi asam sitrat dan 2,797 untuk asam oksalat.

TOA merupakan tertier amin, dimana gugus amine berfungsi sebagai hydrogen acceptor dapat berfungsi sebagai extracting power bagi asam karboksilat (asam sitrat dan asam oksalat) yang mempunyai kemampuan sebagai hydrogen donor. Interaksi antara TOA dan asam karboksilat menghasilkan koefisien aktifitas lebih kecil dari satu atau dengan kata lain menunjukkan penyimpangan negatif terhadap hukum Raoult, sehingga extracting power ini akan memberikan koefisien distribusi yang besar. Dodecane termasuk kelompok non hydrogen bonding dimana interaksinya dengan asam karboksilat mempunyai koefisien aktifitas sama dengan 1 atau dengan kata lain menunjukkan penyimpangan nol terhadap hukum Raoult, akan menghasilkan koefisien distribusi yang tidak besar (Robbins, 1980). Sebagaimana ditunjukkan pada Tabel 1, dodecane mempunyai koefisien distribusi yang sangat kecil yaitu 0,043 (untuk ekstraksi asam sitrat) dan 0,119 (untuk ekstraksi asam oksalat). Dodecane dengan sifat hidropobisitasnya yang tinggi lebih berfungsi sebagai carrier dari extractant. Hal ini terbukti setelah TOA dan dodecane digabung, koefisien distribusi TOA meningkat menjadi $2-3$ kali lipat.

Penambahan tributyl phosphat (TBP), hexanol, atau octanol ke dalam campuran TOA-dodecane yang membentuk campuran solven baru menunjukkan bahwa ketiga solven campuran tersebut memperlihatkan performa yang lebih baik dibanding TOA secara individual. Artinya TBP, hexanol maupun octanol mempunyai pengaruh atau fungsi. TBP merupakan senyawa phosphate yang mempunyai kemampuan menerima hidrogen (hydrogen acceptor) sebagaimana TOA, sehingga TBP dalam hal ini meningkatkan fungsi TOA sebagai extracting power.

n-Hexanol maupun n-octanol merupakan alkohol rantai panjang yang interaksinya dengan asam karboksilat di dalam diagram Robbins juga menunjukkan penyimpangan negatif terhadap hukum Raoult.

Tabel 1. Koefisien distribusi asam sitrat dan asam oksalat pada berbagai jenis solven campuran

\begin{tabular}{|c|c|c|c|c|}
\hline \multirow{2}{*}{$\begin{array}{c}\text { SOLVEN } \\
\text { (perbandingan berat) }\end{array}$} & \multicolumn{2}{|c|}{ Asam Sitrat } & \multicolumn{2}{|c|}{ Asam Oksalat } \\
\hline & Koef. Distr. & \% Terekstrak & Koef. Distr. & \% Terekstrak \\
\hline $\begin{array}{c}\mathrm{TOA}=15 \% ; \text { dodecane }=70 \% \\
\mathrm{TBP}=15 \%\end{array}$ & 0,352 & 46,74 & 2,383 & 82,69 \\
\hline $\begin{array}{c}\text { TOA }=15 \% ; \text { dodecane }=70 \% ; \\
\text { Hexanol }=15 \%\end{array}$ & 1,154 & 74,22 & 3,779 & 88,31 \\
\hline $\begin{array}{c}\text { TOA }=15 \% ; \text { dodecane }=70 \% ; \\
\text { octanol }=15 \%\end{array}$ & 1,026 & 71,97 & 3,416 & 87,23 \\
\hline TOA $=15 \% ;$ dodecane $=85 \%$ & 0,415 & 50,90 & 5,870 & 92,15 \\
\hline $\mathrm{TOA}=100 \%$ & 0,126 & 23,93 & 2,797 & 84,84 \\
\hline Dodecane & 0,043 & 9,80 & 0,119 & 19,29 \\
\hline $\begin{array}{l}\text { PERBANDINGAN } \\
\text { SOLVEN : DILUEN }\end{array}$ & \multicolumn{2}{|c|}{$(2.5: 1)$} & \multicolumn{2}{|c|}{$(2: 1)$} \\
\hline
\end{tabular}


Untuk itu maka kedua alkohol ini dapat berfungsi sebagai extracting power, sehingga dapat berfungsi sebagai penguat terhadap TOA. Dari Tabel 1 menunjukkan bahwa performa solven campuran yang menggunakan hexanol lebih baik dibanding yang menggunakan octanol. Keduanya sebagai hydrogen donor, namun karena kelarutan hexanol dalam diluen $(0.6 \mathrm{~g} / 100 \mathrm{~g}$ air $)$ lebih besar dibanding dengan octanol (0.05 g/100g air), maka kemungkinan hexanol berpenetrasi ke diluen lebih mudah sehingga memungkinkan lebih banyak terbentuknya ikatan hidrogen dengan asam, yang menandakan jumlah solut yang bisa terekstrak.

Dalam hal ekstraksi asam oksalat sebagai solut, sistem solven TOA-dodecane masih unggul dibanding ketiga solven campuran, sebaliknya pada ekstraksi asam sitrat, solven campuran TOAdodecane-hexane menunjukkan performa yang paling unggul dibanding yang lain. Dari semua uraian yang sudah dituliskan dimuka dan hasil kuantitatif yang ditunjukkan pada Tabel 1, maka secara umum campuran solven yang dapat meningkatkan koefisien distribusi maupun jumlah solut yang dapat terekstrak adalah kombinasi dari $15 \%$ TOA, $70 \%$ dodecane, dan $15 \%$ hexanol.

\section{KESIMPULAN}

Hasil penelitian menunjukkan bahwa perbandingan solven dan diluen yang optimum adalah 2,5:1 untuk ekstraksi asam sitrat dan 2:1 untuk ekstraksi asam oksalat, dimana menghasilkan persentase solut yang terekstrak dan koefisien distribusi terbesar.

Solven campuran dengan komposisi $15 \%$ trioctyl amine, $70 \%$ dodecane dan $15 \%$ hexanol menghasilkan koefisien distribusi dan persentase pemisahan solute yang terbesar pada perbandingan diluen dan solven tertentu.

\section{DAFTAR PUSTAKA}

Burke, J., (1984), Solubility Parameters: Theory and Application, The AIC Book and Paper Group Annual, Volume 3, Craig Jensen Editor, 13-58.

Burrell, H., (1968), The Challenge of the Solubility Parameter Concept, Journal of Paint Technol., 40: No. 520

Choudhury, B., Basha, A., and Swaminathan, T., (1998), Study of Lactic Acid Extraction with Higher Molecular Weight Aliphatic Amines, J. Chem. Tech. Biotechnol., 72: 111.

Hong, K.Y. and Hong, W.H., (2005), Removal of Acetic Acid from Aqueous Solutions Containing Succinic Acid and Acetic Acid by Tri-NOctylamine, Sep. Purif. Technol., 42: 151

Ingale, M.N. and Mahajani, V.V., (1996), Recovery of Carboxylic Acids, C2-C6, from Anaqueous Waste Stream Using Tributylphosphate (TBP):
Effect of Presence of Inorganic acids and Their Sodium Salts, Separations Technology, 6: 1-7.

Jos, B., (2005), Ekstraksi Asam Tartrat dan Asam Malat: Pengaruh Tri (6-Methyl Heptyl) Amin sebagai Extracting Power dalam Berbagai Solven terhadap Koefisien Distribusi, Reaktor.

Juang, R-S. and Huang, R-H., (1997), Equilibrium Studies on Reactive Extraction of Lactic Acid with an Amine Extractant, Chem. Eng. J., 65: 47.

Kirsch, T., Ziegenfu, H., and Maurer, G., (1997), Distribution of Citric, Acetic and Oxalic Acids between Water and Organic Solutions of Tri-NOctylamine, Fluid phase Equilib., 129: 235-266.

Kirsch, T. and Maurer, G., (1997), Distribution of Citric, Acetic and Oxalic Acid between Water and Organic Solutions of Tri-N-Octylamine. Part I. Organic Solvent Toluene, Fluid phase Equilib., 131: 213-231.

Kirsch, T. and Maurer, G., (1998a), Distribution of Binary Mixtures of Citric Acetic and Oxalic Acid between Water and Organic Solutions of Tri-NOctylamine. Part II. Organic Solvent Methylisobutylketone, Fluid phase Equilib., 142: 215230.

Kirsch, T. and Maurer, G., (1998b), Distribution of Binary Mixtures of Citric Acetic and Oxalic Acid between Water and Organic Solutions af Tri-NOctylamine. Part III. Organic Solvent Chloroform, Fluid phase Equilib., 146: 297-313.

Kyuchoukov, G., Marinova, M., Molinier, J., Albet, J. and Malmary, G., (2001), Extraction of Lactic Acid by Means of A Mixed Extractant, Ind. Eng. Chem. Res., 40: 5635 .

Malmary, G., Albet, J., Putranto, A., Hanine, H. and Moliner, J., (1998), Measurement of Partition Coefficients of Carboxylic Acids between Water and Triisooctylamine Dissolved in Various Diluents, $J$. Chem. Eng. Data., 43: 849.

Marinova, M., Kyuchoukov, G., Albet, J., Moliner, J. and Malmary, G., (2004), Separation of Tartaric and Lactic Acids by Means of Solvent Extraction, Sep. Purif. Technol., 37: 199-207.

Morrison, R.T. and Boyd, R.N., (1992), Organic Chemistry, $6^{\text {th }}$.ed. Englewood Clift, New Jersey: Prentice Hall.

Perry, R.H. and Green, D., (1984), Perry's Chemical Engineers Handbook, $6^{\text {th }}$ ed. Mc Graw Hill Book Co. New York.

Poposka, F.A., Nikolovski, K., and Tomovska, R., (1998), Kinetics, Mechanism and Mathematical Modeling of Extraction of Citric Acid with Isodecanol/N-Paraffins Solutions of Trioctylamine, Chem. Eng. Sci., 53: 3227-3237. 
Poposka, F.A., Prokhazka, J., Tomovska, R., Nikolovski, K. and Grizo, A., (2000), Extraction of Tartaric Acid from Aqueous Solutions with Tri-IsoOctylamine: Equilibrium and Kinetics, Chem. Eng. Sci., 55: 1591.

Qin, W., Cao, Y., Luo, X., Liu, G. and Dai, Y., (2001), Extraction Mechanism and Behavior of Oxalic Acid by Trioctylamine, Sep. Purif. Technol., 24: 297.

Robbins, L.A., (1980), Liquid-Liquid Extraction. In: Perry, R.H., Green, D., Perry's Chemical Engineers Handbook, $6^{\text {th }}$ ed. Mc Graw Hill Book Co. New York.
Schunk, A., Menert, A., and Maurer, G., (2004), On the Influence of Some Inorganic Salts on the Partitioning of Citric Acid between Water and Organic Solutions of Tri-N-Octylamine. Part I: Methyl Isobutyl Ketone as Organic Solvent.

Tomovska, R., Poposka, F.A., Heyberger, A. and Prochazka, J., (1999), PH Dependence of Tartaric Acid Extraction, Chem. Biochem. Eng., 13: 185.

Wade, L.G., (1999), Organic Chemistry, New Jersey: Prentice Hall.

Yankov, D., Moliner, J., and Kyuchoukov, G., (1999), Extraction of Tartaric Acid by Trioctylamine, Bulg. Chem. Comm., 31: 446. 